\title{
Comparison between tympanic and anal temperature with a clinical infrared ray thermometer in dogs
}

\author{
[Comparação entre a temperatura timpânica e a temperatura anal usando \\ um termômetro clínico de raio infravermelho em cães]

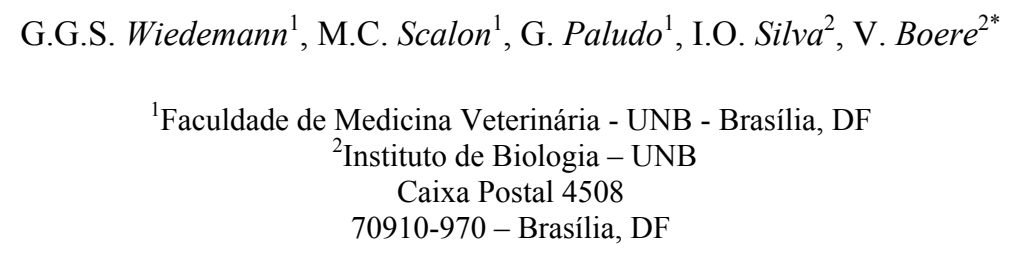

\begin{abstract}
A clinical thermometer of infrared rays was used twice to record consecutively the temperature of the tympanic membrane in each ear and in the anus of 53 dogs. Temperatures did not differ significantly between organs, and were strongly correlated. The anal temperature measurement with an infrared thermometer in dogs is feasible and trustworthy, as well as the thermal checking of tympanic temperature.
\end{abstract}

Keywords: dog, tympanic temperature, thermometer

\section{RESUMO}

Utilizou-se um termômetro clínico de emissão de raios infravermelhos para medir, duas vezes consecutivas, a temperatura da membrana timpânica de cada ouvido e duas vezes a temperatura no ânus de 53 cães. Não houve diferença entre as temperaturas quanto ao órgão estudado e a correlação entre as temperaturas foi alta. Em cães, a medida da temperatura anal com o termômetro clínico de emissão de raios infravermelhos é rápida e confiável tanto quanto a da temperatura timpânica.

Palavras-chave: cão, temperatura timpânica, termômetro.

\section{INTRODUCTION}

Measurement of tympanic membrane temperature (TT) through infrared thermometers is a recent procedure in veterinary routine and seems to present methodological and economical advantages (Robinson et al., 1998; Bergen and Kennedy, 2000; Stavem et al., 2000). The measurement of the TT through an infrared thermometer presents advantages compared to rectal measure temperature (RT) with regular clinical thermometers, the most used method for thermal clinical checking in animals. RT method can present lower accuracy due to variation on the portion of the rectum measured, variations of local blood flow and the presence of feces (Robinson et al., 1998). RT is not faster than TT method and we have observed a relative long lasting to RT method in dogs (>90s). Besides, an indocile and agitated patient can precipitate wounds in the rectum during the procedure.

Generally, corporal temperature measurement of dogs requires its manual restraint, which is not

Recebido em 27 de agosto de 2004

Aceito em 30 de janeiro de 2006

*Autor para correspondência (corresponding author)

E-mail: vanner@unb.br

Apoio: FINATEC/UNB - DPP/UNB 
easy when the veterinarian is checking an unquiet and reactive patient. In this case, wrong measurement could compromise interpretation, diagnostic and therapeutic strategy. Alternative ways of temperature checking in the dog could be useful and practical to veterinary procedures. The objective of this study was to compare the body thermal temperature measured with a veterinary infrared thermometer on the tympanic membrane and anus in dogs.

\section{MATERIALS AND METHODS}

Tympanic and anal temperatures of 53 adult dogs from several pure breeds and crossbreed were measured (18 males and 35 females). Dogs with fever $\left(\geq 39^{\circ} \mathrm{C}\right)$ or with severe disease were not included in the samples. Data collection was carried at 9AM and 5PM.

TT was measured with a self-calibrating thermometer $^{1}$ that measures the infrared heat generated by the eardrum and surrounding tissues. This thermometer records eight measurements in one second and displays the highest temperature. Dogs were resting when the veterinarian softly lifted upward and backward the auricular pavilion. TT was twice measured in each ear, alternately. Immediately, anal temperature (AT) was measured. The temperature was measured for two consecutive times, positioning the thermometer perpendicularly at a distance of $0.5 \mathrm{~cm}$ to the anus. The time elapsed between the first and the last measurement was 30 to 60 seconds.

Data were presented as the average of the right tympanic temperature (RTT), left tympanic temperature (LTT) and AT. Differences among RTT, LTT and AT were analysed by a pairedsample $\mathrm{T}$ test (two-tailed) and Pearson correlation test was applied. Significance level in all the tests was considered $\mathrm{P} \leq 0.05$.

\section{RESULTS AND DISCUSSION}

The comparative analysis (Table 1) indicated that RTT, LTT and AT means were not significantly different. High positive correlations between RTT, LTT and AT, were observed.

Right and left tympanic membrane, as well as anus, are body structures liable to obtain temperature in dogs, considering the correlationship between RTT, LTT and RT.

Table 1. Means, standard errors (SE), correlations and level of significance $(P)$ of the right tympanic temperature (RTT), left tympanic temperature (LTT) and anal temperature of dogs

\begin{tabular}{lccccc} 
& \multicolumn{2}{c}{ Range } & Mean \pm SE & \multicolumn{3}{c}{ Correlation $(\mathrm{P})$} \\
\cline { 4 - 6 } & $\left({ }^{\circ} \mathrm{C}\right)$ & $\left({ }^{\circ} \mathrm{C}\right)$ & RTT & LTT & AT \\
\hline RTT & $34.0-39.10$ & $37.20 \pm 0.89$ & - & 0.63 & $0.30(0.031)$ \\
LTT & $35.6-39.75$ & $37.29 \pm 0.89$ & & - & $0.43(0.002)$ \\
AT & $34.75-39.0$ & $37.41 \pm 1.15$ & & & \\
\hline
\end{tabular}

The method of TT measurement for thermal checking in patients is recent in veterinary procedure. The rapidity and the safety to get corporal temperatures with a tympanic thermometer of infrared rays are advantages concerning this method. However, the ear is a sensible region and painful injuries or

${ }^{1}$ PetTemp, Advanced Monitors, San Diego, USA. inflammatory processes routinely restrain the use of this technique. Very unmanageable animals can hamper a measurement with accuracy. Alternatively, the results suggest that measurements of the body temperature in normothermic dogs can be reliable if carrying through the anal measurement method. 
The higher correlation bettween AT and LTT in comparison to the correlation between AT and RTT is a point of interest. To the present knowledgement, there are no evidences of an important anatomical difference of the blood perfusion in the right or left tympanic membrane in dogs. Right tympanic membrane is irrigated with arterial tributaries from maxillary, and left tympanic membrane is irrigated with arterial tributaries from superficial temporal, maxillary and internal carotid in primates and rodents (Baker et al., 1972; Meiners and Dabbs, 1977; Albiin et al, 1985). This anatomical evidence proves that the tympanic membrane irrigation is a result of the blood brain flux. As it was suggested, the tympanic temperature reflects with confidence the degree of ipsilateral brain metabolism (Meiners and Dabbs, 1977; Boyce et al., 2002; Tomaz et al., 2003). However, it is not known to the certainty whether the gradient of the tympanic membrane temperature is related to an increased or diminished cerebral metabolism, due vasodilatation effects of the $\mathrm{CO}_{2}$ (carbon dioxide) metabolism, and NO (nitric oxide) from the autonomic vascular reflex (Tomaz et al., 2003). Whatever be the interpretation, in dogs, seems to be sufficiently reliable the measurement of the anal temperature with a thermometer of emission of infra-red rays to evaluate the central body temperature. The ability to obtain a right record of anal temperature depends on the training and experience to manipulate the apparatus. The anal method of thermal checking with an infrared tympanic thermometer is less invasive and it seems to be viable when other ways are very little feasible.

\section{ACKNOWLEDGEMENTS}

We are grateful to Rafael Rocha for data collecting and Dr Christine Martins Souza due to helpful commentaries.

\section{REFERENCES}

ALBIIN, N.; HELLSTROM, S.; SALEN, B. et al. The vascular supply of the rat tympanic membrane. Anat. Rec., v.212, p.17-22, 1985.
BAKER, M.A.; STOCKING; R.A., MEEHAN; J.P. Thermal relationship between tympanic membrane and hypothalamus in conscious cat and monkey. J. Appl. Physiol., v.32, p.739-742, 1972.

BERGEN, R.D., KENNEDY, A.D. Relationship between vaginal and tympanic membrane temperature in beef heifers. Can. J. Animal Sci., v.80, p.515-518, 2000.

BOYCE, W. T.; ESSEX, M. J.; ALKON, A. et al. Temperament, tympanum, and temperature: four provisional studies of the biobehavioral correlates of tympanic membrane temperature asymmetries. Child Develop., v.73, p.718-733, 2002.

HACHIMI-IDRISSI, S.; CORNE, L.; EBINGER, G. et al. Mild hypothermia induced by a helmet device: a clinical feasibility study. Resuscitation, v. 51, p. 275-271, 2001.

MEINERS, M.L.; DABBS, J.M. Ear temperature and brain blood flow: Laterality effects. Bull. Psychon. Soc., v.10, p.194-196, 1977.

ROBINSON, J.; SEAL, R.; SPADY, D. et al. Comparison of oesophageal, rectal, axillary, bladder, tympanic and pulmonary artery temperatures in children. J. Pediat., v.133, p.553-556, 1998.

STAVEM, K.; SAXHOLM, H.; ERIKSSEN, J. Tympanic or rectal temperature measurement? A cost-minimization analysis. Scand. J. Infec. Dis., v.32, p.299-301, 2000.

TOMAZ, C.; VERBURG, M. S.; BOERE, V. et al. Evidence of hemispheric specialization in marmosets (Callithrix penicillata): a study using tympanic membrane thermometry. Braz. J. Med. Biol. Res., v.36, p.913-918, 2003.

WELLS, D.L. Lateralized behaviour in the domestic dog. Canis familiaris. Behav. Proc., v.61, p.27-35, 2003.

WHITE, M.D.; CABANAC, M. Respiratory heat loss and core temperatures during submaximal exercise. J. Therm. Biol., v.20, p.489-496, 1995. 